\title{
空間相関分析法の道路ネットワーク空間への拡張 EXTENSION OF SPATIAL CORRELATION ANALYSIS METHOD TO ROAD NETWORK SPACE
}

\author{
大佛俊泰*，内藤智之**
}

\section{Toshihiro OSARAGI and Tomoyuki NAITO}

\begin{abstract}
The spatial correlation analysis (SCA) method was proposed in order to analyze urban activities quantitatively. This paper attempts to extend the method of SCA defined in the bi-dimensional Euclidean space to the road-network space. We discuss a method for applying the spatial correlation analysis in the road-network space and illustrate the details of computation methods. As the numerical examples using actual GIS data, the comparison of results from the Euclidean distance and the network distance is shown. Also, we demonstrate some case studies using the variety of computation methods.
\end{abstract}

Keywords : Spatial Correlation Analysis Method, Network Distance, Euclidean Distance, Spatial Correlation Function 空間相関分析法，ネットワーク距離，ユークリッド距離，空間相関関数

\section{1. はじめに}

都市・地域計画においては，現状の都市や地域の状態を把握する ことは欠かせない。特に空間的に分布している様々な特性を定量的 に把握する方法として, K 関数法 ${ }^{1)}$, 最近隣法 ${ }^{2), 3)}$, Join 分析 ${ }^{4)}$, Clump 分析 ${ }^{5)}$, Moran $の I$ 統計量 ${ }^{6)}$ ，空間相関分析 ${ }^{6)}$ といった手法 が提案されている。これらの手法のうち，本稿で扱う空間相関分析 法は，相関係数の概念を二次元空間に拡張した空間相関関数を用い て，距離的に離れた 2 点間の都市活動要素の空間的な相関関係を分 析するものである。空間相関分析法の起源は古く, 1950 年代後半 から 1960 年代初頭にかけて米国の地理学分野を中心に展開された “計量革命”に遡る。当時の議論の中核となった空間的自己相関の 概念は同種の要素間の空間的な相関関係を表すもので, Andrew D. Cliff と J. Keith $0 \mathrm{rd}^{6)}$ によって展開・一般化され，地理学のみ ならず，計量経済学，生態学，疫学，都市計画などの幅広い分野に 応用されてきた。また，K 関数法，Join 分析といった空間分析法 の基礎となった概念でもある ${ }^{7)}$ 。空間相関分析法は，都市・建築分 野において都市活動要素の空間的な関係性を把握するために用いら れ，日本では青木による研究 ${ }^{8)}{ }^{-10)}$ がその端緒となっており，異種 の都市活動要素間の空間的な影響関係を定量的に分析する手法 ( 空
間影響関数モデル)へと展開している。

これらの空間相関分析法に関する一連の分析は，二次元連続空間 の仮定のもと, 都市要素間の距離がユークリッド距離により定義さ れてきた。しかし，現実の都市空間では，人や物は直線的にではな く道路上を移動することから，施設間の空間的な関係性を分析する 上では，従来までの仮定は，幾分強い仮定であると考えられる。一 方，腰塚ら ${ }^{11)}$ によれば，道路密度の高い都市内においては，これ らふたつの距離間には美しい比例の関係があるとされているが，ネ ットワークに沿って分布している都市活動要素をより精緻に分析し ようとする場合には，連続空間上でユークリッド距離を使って分析 するより，ネットワーク空間上でネットワーク距離を使って分析す る方が望ましいと考えられる。

こうした要請と, 近年のデジタル空間データの高精度化を背景と して，道路ネットワーク上の各種施設を対象とした分析方法が岡部 らを中心として開発されてきている注1)。

そこで本研究では，道路ネットワーク上で空間相関分析を行う ための方法を構築し，その有効性について検討を行う。まず，第 2 章では空間相関の基礎概念をネットワークに適用するための方法に ついて検討する。つづいて第 3 章では分析対象や目的に応じた様々

\footnotetext{
本稿は文献19），20）をもとに，加筆，修正を加えたものである。

* 東京工業大学大学院情報理工学研究科 准教授. 博士 (工学)

** 東京工業大学大学院情報理工学研究科 修士課程
}

Assoc. Prof., Graduate School of Information Science and Engineering, Tokyo Institute of Technology, Dr. Eng.

Graduate Student, Graduate School of Information Science and Engineering, Tokyo Institute of Technology 
な計算方法のバリエーションを提案する。次に第 4 章，第 5 章では ここで提案した分析方法の有効性について分析事例をもとに検証す る。最後に第 6 章で本稿を総括する。

\section{2. ネットワーク空間相関分析}

\section{1. 基礎概念}

空間相関分析法を導入するにあたり，ネットワーク上で空間的に 離れたふたつの地点における相関概念を定義することから始める。 ここで示寸空間相関概念を利用することで，都市の諸活動の空間的 な連続性，相互関係などが定量的に把握できるようになる。

まず，対象とするネットワークの全体を $L_{T}$ ，その総延長を $l_{T}$ と 表すことにする。このネットワーク上における距離は，2 点間の最 短経路により定義される。また, このネットワーク上の点 $p$ におい て, $m$ 種類の変量 $X_{i}(i=1 \sim m)$ の值 $x_{i p}$ が与えられているとする。 さて, 空間相関分析法では, ある地点の変量とそこから一定距離 離れた地点の変量との相関関係を分析する。二次元連続空間におい て，「距離」と「方向」の情報を保持して分析すれば，ある地点か ら $x$ 方向 $y$ 方向にそれぞれ $\Delta x, \Delta y$ 離れた地点は一意に定まった。 しかし, ネットワーク空間上で, ある地点から一定距離 $\Delta l$ 離れた ような地点は（「方向」に関する情報を使わない時）複数存在する 場合があり，離れた 2 地点を一対一で対応付けをすることが困難で ある (図 1)。そこで, $L_{T}$ 上の任意の一点 $p$ から $\tau$ 離れた地点の集 合を $P_{\tau}=\left\{p_{\tau(1)}, \ldots, p_{\tau\left(n_{p \tau}\right)}\right\}$ と表し，これら $n_{p \tau}$ 個の地点における $x_{i}$ の值の平均值を $x_{i p}(\tau)$ と定義する。すなわち,

$$
x_{i p}(\tau)=\sum_{k=1}^{n_{p \tau}} x_{i p_{\tau(k)}} / n_{p \tau}
$$

となる。特に $\tau=0$ のとき, $x_{i p}(\tau)$ は $x_{i p}$ の值そのものとなる。ここ で定義した $x_{i p}(\tau)$ のネットワーク全体での期待值を $\overline{x_{i}}(\tau)$ と表記す ることにすれば，相互空間共分散関数 $C_{i j}(\tau)$ を算出するには，点 $p$ をネットワーク全体 $L_{T}$ 上を動かしながら， $x_{i p}(0)$ と $x_{j p}(\tau)$ の共分 散の期待値を計算すればよい。すなわち,

$$
C_{i j}(\tau)=\frac{1}{l_{T}} \int_{p \in L_{T}}\left(x_{i p}(0)-\bar{x}_{i}(0)\right) \cdot\left(x_{j p}(\tau)-\bar{x}_{j}(\tau)\right) d p
$$

これを用いて相互空間相関関数 $R_{i j}(\tau)$ は次式で定義される。

$$
R_{i j}(\tau)=C_{i j}(\tau) / \sqrt{V_{i}(0) \cdot V_{j}(\tau)}
$$

ただし，

$$
\begin{aligned}
& V_{i}(0)=\frac{1}{l_{T}} \int_{p \in L_{T}}\left(x_{i p}(0)-\bar{x}_{i}(0)\right)^{2} d p \\
& V_{j}(\tau)=\frac{1}{l_{T}} \int_{p \in L_{T}}\left(x_{j p}(\tau)-\bar{x}_{j}(\tau)\right)^{2} d p
\end{aligned}
$$

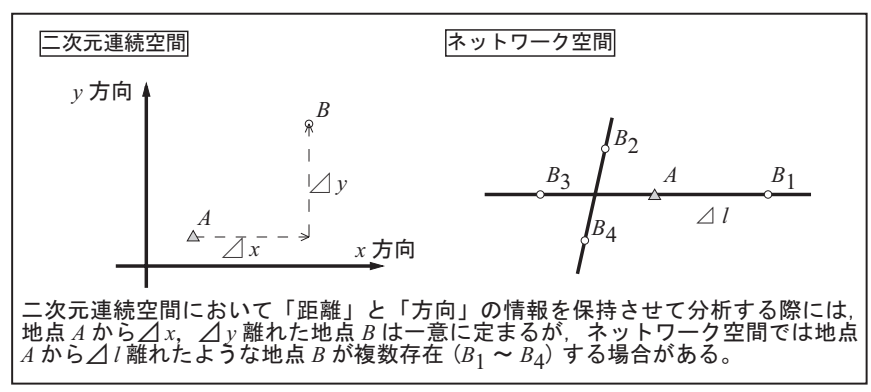

図 1 二次元連続空間とネットワーク空間の違い

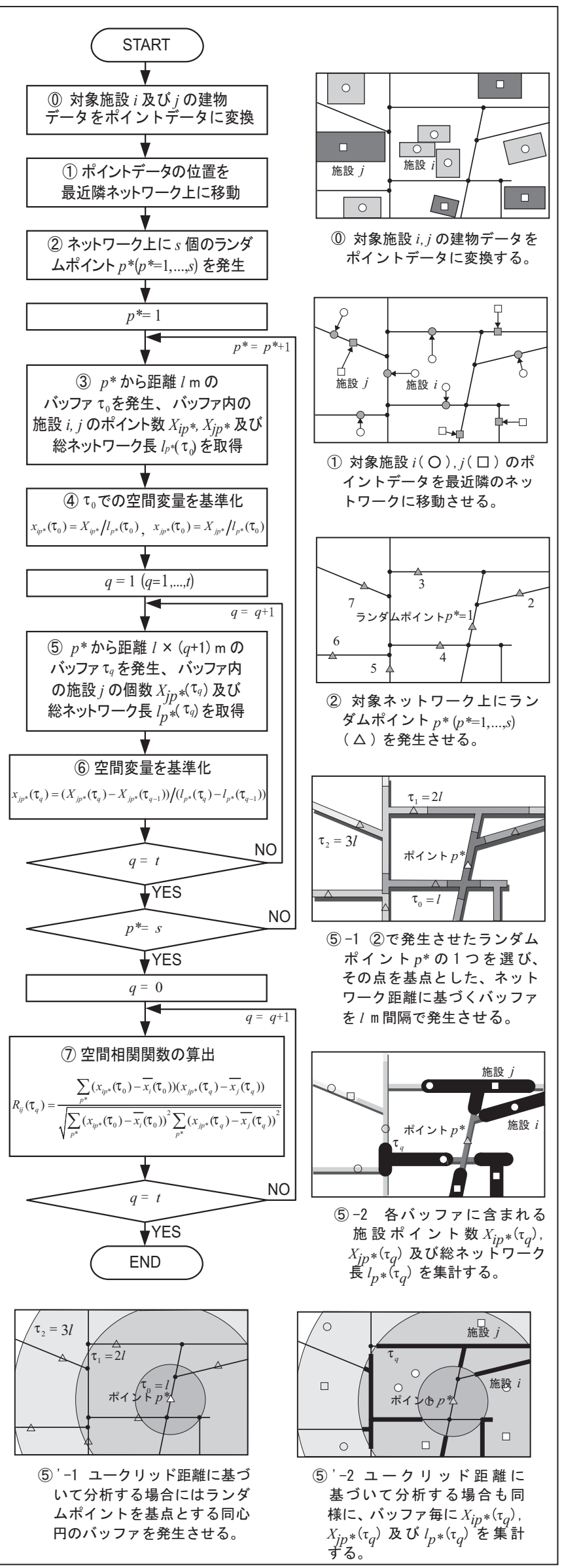

図 2 ネットワーク空間相関分析の手順 
$R_{i j}(\tau)$ の值は-1 以上 1 以下の值をとる。ある場所の変量 $X_{i}$ とそ こから $\tau$ ずれた場所の変量 $X_{j}$ の相関係数が 1 に近い場合, 両者には 「共存性」があり，逆に，-1に近い場合は両者には「排斥性」があ ることになる。

また，特に $i=j$ のと，すなわち同一の変量について上記の定義 を当てはめて求めた関数は, 自己空間相関関数と呼ぶ。この值が 1 に近い場合は，同一の都市活動の空間的な分布傾向が連続している ことを示しており，「連担性」があると表現する。

\section{2. 地図データを用いた場合の計算方法}

以上では，連続分布する空間変量を前提として議論した。以下で は，この基礎概念に基づいて，実際の地図データを用いて分析する ための方法を示す。実際の地図データを用いて分析するにあたって は，個々の住宅施設など点分布する変量を扱うことが非常に多い。 従来の二次元空間における分析では, 実際の地図データを用いる 際，対象地域を形状と面積が同一の格子に区切ったメッシュデータ を用いて，点分布を離散分布に密度変換して相関関係を分析してい た。ネットワーク空間においても，二次元空間におけるメッシュの ように，ネットワーク全体をそれぞれのネットワーク長が等しくな るようにセルに分割する方法が考案されている ${ }^{17)}$ 。しかし，区切 られたセル間にはメッシュデータのように，2 地点間の等距性が厳 密には保存されていない注2)。すなわち，あらかじめ等しい長さに 区切られたネットワークデータを用意して分析することは難しい。 そこで，ここでは，図 2 に示すようなネットワーク上に発生させた ランダムポイントを利用し，ランダムポイントを起点とした等間隔 のバッファをもとに地域の空間変量を離散分布に変換する方法をと る ${ }^{\text {注 } 3)}$ 。図 2 に具体的な計算手順, および, 離散分布を前提とした 式を示してある。ここでは，空間変量が，建物の用途と地点である ような場合を例に説明する。

まず $(0)$ 分析対象施設 $i$ の建物データをポイントデータに変換 し，(1）全てのポイントを最近隣ネットワーク上に移動させる。次 に（2）ネットワーク上にランダムにポイント $p^{*} \quad\left(p^{*}=1, \ldots, s\right)$ を

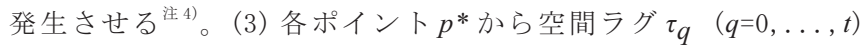
をもつバッファを順次発生させる。（4）ポイント $p^{*}$ を基点とする 各バッファ内に含まれる集計量 $X_{i p} *\left(\tau_{q}\right)$ とネットワークの総長 $l_{p} *\left(\tau_{q}\right)$ を求める。さらに(5) $X_{i p} *\left(\tau_{q}\right)-X_{i p} *\left(\tau_{q-1}\right)$ の 值 を $l_{p} *\left(\tau_{q}\right)-l_{p} *\left(\tau_{q-1}\right)$ の值で除し, ネットワーク長さあた りの量 $x_{i p} *\left(\tau_{q}\right)$ を求める。(6) 空間的自己相関関数の值 $R_{i i}\left(\tau_{q}\right)$ は, ランダムポイント $p^{*}$ 毎に得られる空間変量 $x_{i p} *\left(\tau_{0}\right)$ と $x_{i p} *\left(\tau_{q}\right)$ の相関係数として求めることができる。また, 対象施 設 $j$ についても同様に変量 $x_{j p} *\left(\tau_{q}\right)$ を構成し， $x_{i p} *\left(\tau_{0}\right)$ との相関 係数を求めると空間的相互相関関数の值 $R_{i j}\left(\tau_{q}\right)$ となる。

\section{3. 空間変量と計算方法のバリエーション}

以上の方法はネットワーク上に空間距離をもとにバッファを発生 させ，施設数を集計し，バッファ内のネットワークの総長により集 計した空間変量を基準化する方法であるが，分析対象や目的に応じ て以下に示寸計算方法を用いることも可能である。

\section{1. バッファの設定方法について}

空間変量を集計する際のバッファについては，空間距離の他に時
間距離に基づく方法が考えられる。前者は道路上のネットワーク距 離をもとに一定の距離間隔でバッファを順次発生させていく方法で あるのに対し, 後者は一定の時間間隔内での移動距離をもとにバッ ファを発生させる方法である。自動車の利用等を想定して，時間距 離をもとに分析したいような場合には，後者に基づく方がよい。

\section{2. 空間変量について}

各バッファに含まれる施設の空間変量を集計する際には，単に施 設の数を集計する方法の他に, 対象施設の床面積等の連続量を集計 する方法が考えられる。施設の規模まで含めた分析を行う際には, 連続量を用いればよい。

\section{3. 基準化の方法について}

バッファ毎に集計した空間変量は，集計ポイント $p^{*}$ ごとにバッ ファの大きさがそれぞれ異なるため, バッファが受け持つ領域の 大きさで基準化する必要が生じる。基準化の方法はバッファのネッ トワーク長で基準化する方法の他に，バッファが受け持つエリアの 面積で基準化する方法が考えられる (図 3)。バッファがもつネッ トワーク長で基準化する場合，施設の分布が全く同じ場合であって も，道路密度が異なると基準化した空間変量の值は変動してしまう （図 4）。一方, 面積で基準化する場合は道路の密度にかかわらず空 間変量の值は変化しない。すなわち, 道路密度の大きく異なる地域 間で比較分析するような場合には面積で基準化した方がよい。ただ し，住宅の分布などについて分析する場合には，畑や公園などの面 積を差し引いた可住地面積を利用する必要がある。

\section{4. 道路が持つ属性を考慮した分析について}

空間変量を集計する際，道路幅員や用途地域といった道路が持つ 属性ごとに区別して值を集計すれば，異なる属性間での分析を行う ことが可能である。施設の立地傾向が道路が持つ属性によって影響 を受けている場合にはこの方法を用いればよい。

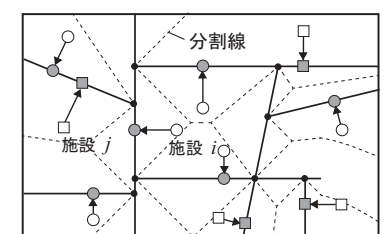

建築物を最近隣のネットワーク 上に移動させる作業は，各ネッ トワークから等距離の地点で領 域を分割し(線的オブジェクト のボロノイ分割に相当)，分割 領域内にある施設を空間変量と して扱うことと等価である。

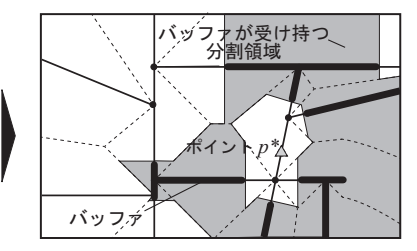

バッファが受け持つ分割領域の 面積は「バッファから到達する ことのできる領域の面積」とい う意味を有している。バッファ 上の空間変量を斜線の領域の面 積で除すことで面積での基準化 を行う。
図 3 面積による基準化

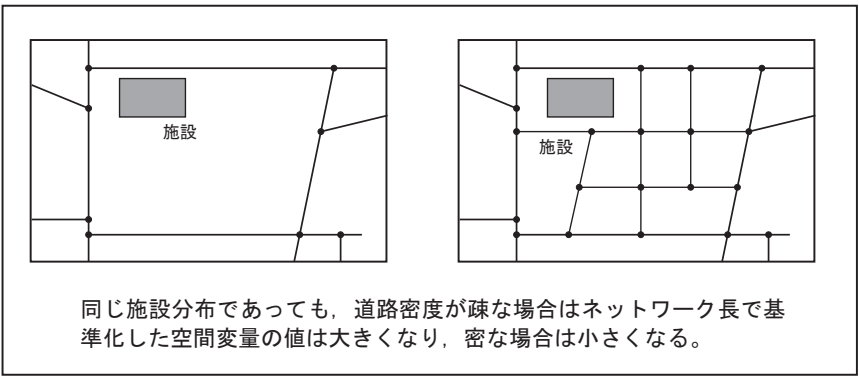

図 4 道路密度の違いによる空間変量の変動 


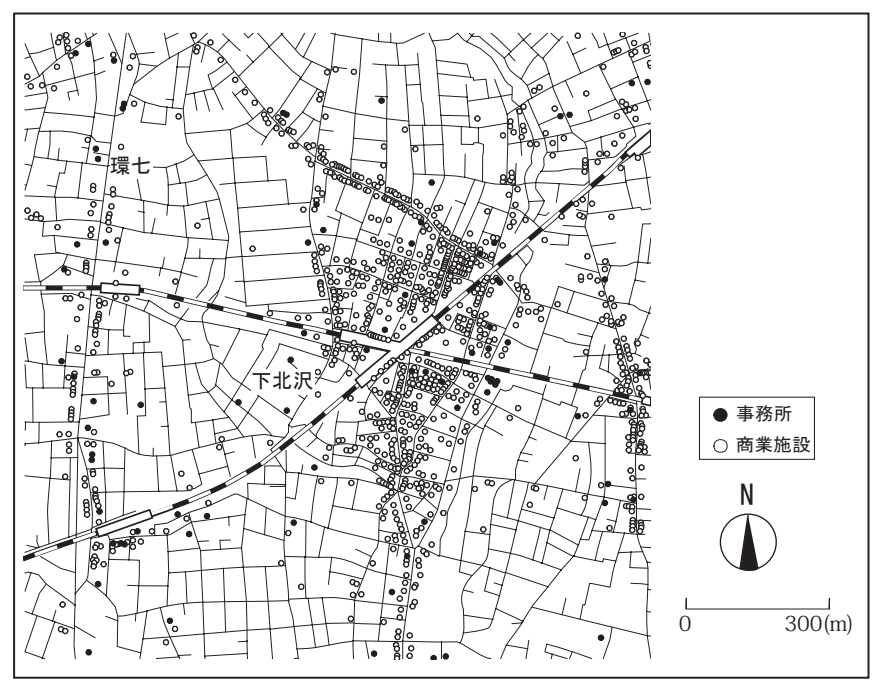

図 5 下北沢周辺地域 (東京都世田谷区)

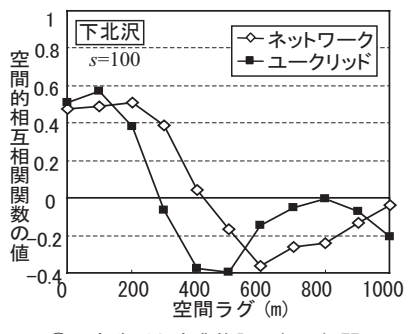

(1) 事務所と商業施設の相互相関

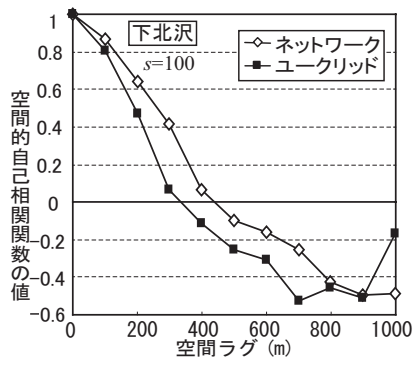

(2) 商業施設の自己相関

図 6 ユークリッド距離とネットワーク距離の分析結果の比較

\section{4. ユークリッド距離とネットワーク距離の比較}

ユークリッド距離に基づく空間相関分析（ユークリッド空間相

関 ) とネットワーク距離に基づく空間相関分析（ネットワーク空間 相関 )の比較を行った。下北沢を中心と寸る地域（図 5) を分析対 象地域として事務所建築物と商業施設の空間的相互相関関数（図 6 (1) ）を求めた。ユークリッド距離を用いた場合には，空間ラグの小 さい範囲での相互相関の值は高いが， $200 \mathrm{~m}$ 付近で急激に減衰して いる。これに対し，ネットワーク距離を用いた場合は距離減衰が小 さいことがわかる。二次元連続空間では隣接する施設間も，ネット ワーク空間では迂回してアクセス寸る必要があるため，このような 差異が生じたと考えられる。

次に, 商業施設の空間的自己相関関数 (図6 (2) ) を求めた。結 果をみると, ユークリッド距離を用いた場合は值の距離減衰が大き いが，ネットワーク距離を用いた場合には緩やかに減衰しているこ とがわかる。このエリアは 2 本の鉄道によって地域が大きく分断さ れており, 駅周辺を中心として立地している商業施設は分断の影響 を受けやすいため，このような差異が現れたものと考えられる。す なわち, ユークリッド距離の視点からすると施設は相互に隣接し ながら立地し, 1 つのコンパクトな商業集積となっているが, 実際 のネットワーク距離の視点からすると, 線路を渡るなどして迂回し て, ある程度距離をおいて立地しており, 空間的な広がりをもった 商業集積となっているためである。

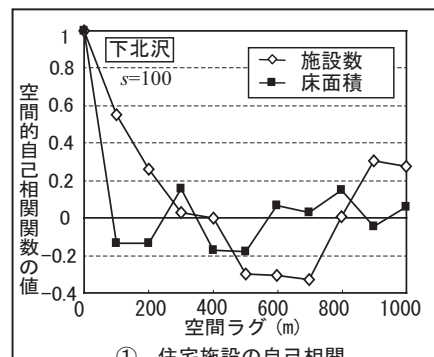

(1) 住宅施設の自己相関

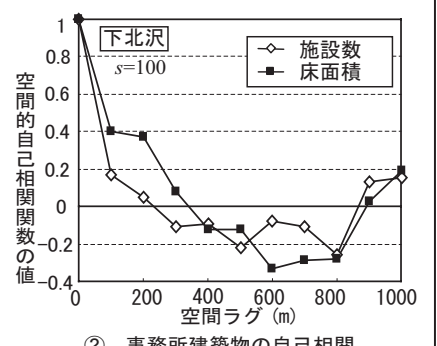

2) 事務所建築物の自己相関

図 7 空間変量の集計方法の比較

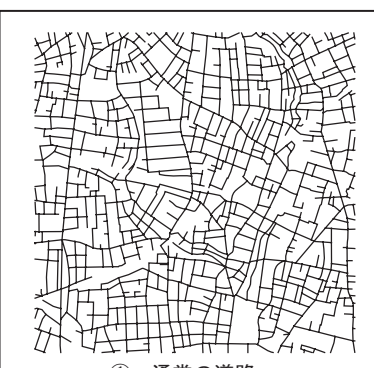

(1) 通常の道路

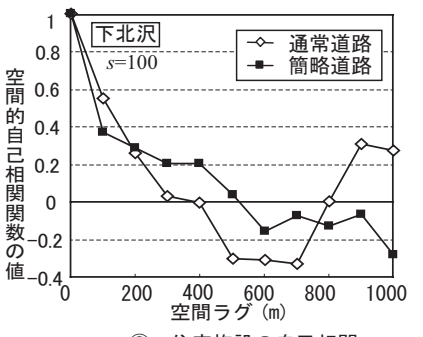

(3) 住宅施設の自己相関 (ネットワーク長による基準化)

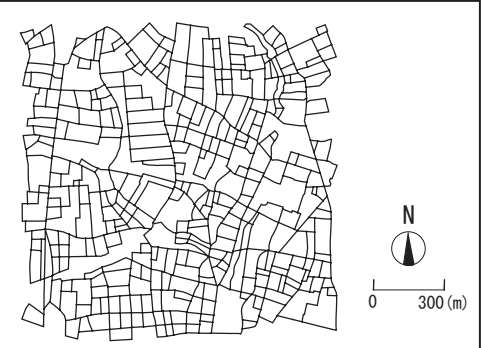

(2) 簡略化した道路

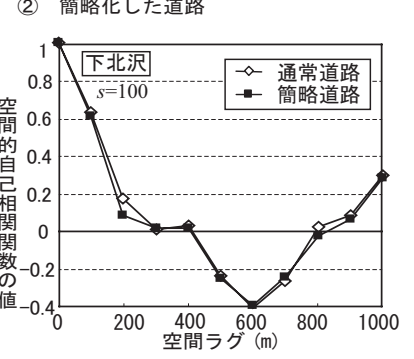
(4) 住宅施設の自己相関
図 8 空間変量の集計方法の比較

\section{5. 空間変量と計算方法の比較}

下北沢周辺（図 5）を分析対象地域として，施設の集計方法別に 空間的自己相関関数を求めた（図 7)。住宅施設についてみると, 施設数を集計した場合の方が床面積を集計した場合よりも空間ラグ $200 \mathrm{~m}$ までの空間的自己相関の值が大きくなった（図 7 (1)）。これ に対し, 事務所建築物については空間ラグが小さい範囲では床面積 を集計した場合の方が值は大きくなった（図 7 (2))。住宅は主要幹 線道路沿いに建つ大規模集合住宅と細街路に密集する戸建住宅が入 り組んで立地しているため, 床面積で集計して分析すると連担性は 小さくなる。一方，事務所建築物は同規模の施設が連続する傾向に あるため，床面積で集計して分析すると高い連担性が観測される。

次に, 面積で基準化する方法の方がリンク長で基準化する方法よ りも，道路の粗密による影響が小さいことを検証する。下北沢周辺 （図 5）を分析対象地域として, 通常の道路ネットワークデータ（図 8 (1) ) の他に, 道路の端部が他の道路に接続していないリンクを削 除して簡略化したデータ（図８（2)）を用意し，それぞれのデータに ついて二つの基準化の方法で住宅施設の空間的自己相関関数を求め た。リンク長により基準化した結果（図８（3)）では, 通常の道路デー タを用いた場合と簡略化した道路データを用いた場合とで大きな違 いが現れている。これに対して，面積により基準化した結果（図8 (4)) では, 両データ間の結果に殆ど差異はみられない。すなわち, 道路密度や道路データの精度が大きく異なる 2 地域間で比較分析を 行うような場合には，面積で基準化する方が望ましい。 


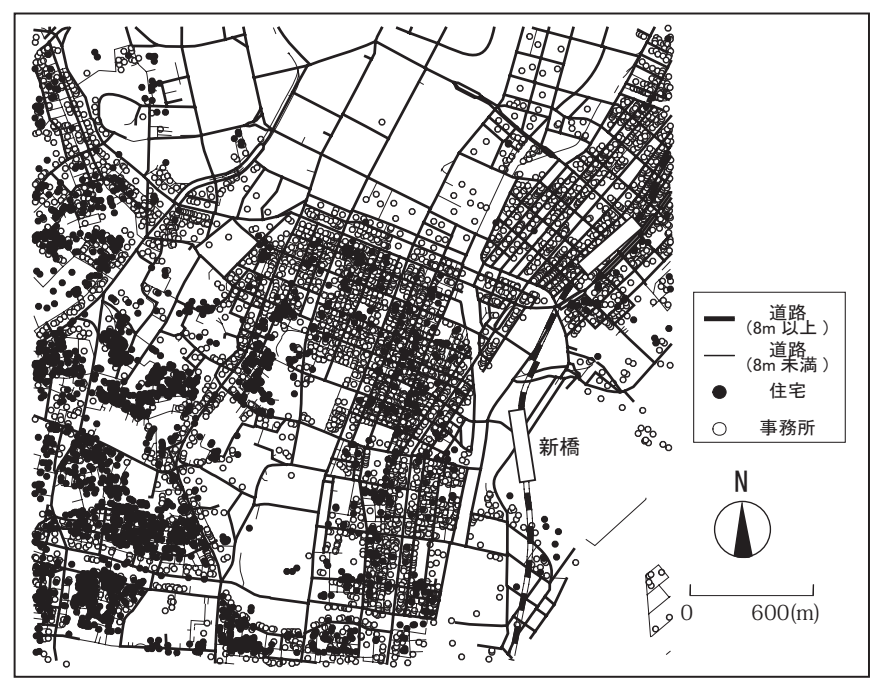

図 9 新橋周辺地域 (東京都中央区)

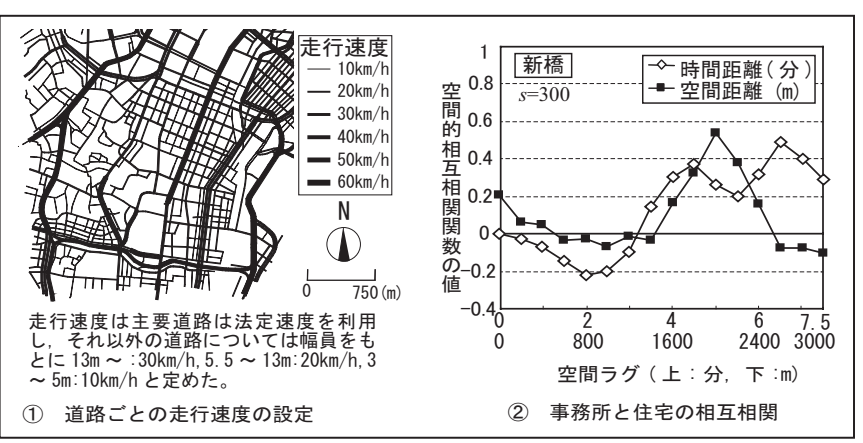

図 10 空間距離と時間距離の分析結果の比較 (新橋周辺)

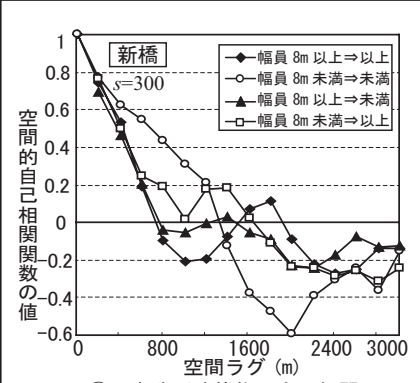

(1) 事務所建築物の自己相関

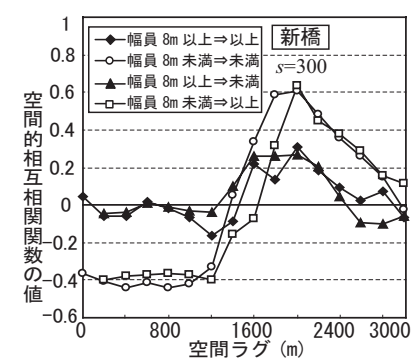

(2) 事務所と住宅の相互相関
図 11 道路幅員を考慮した分析 (新橋周辺)

また，新橋を中心とする地域（図 9）を対象に，自動車利用者を 想定して時間距離に基づいて事務所建築物と住宅施設の相互相関関 数を求めた（図 10 (2))。自動車の走行速度は図 10 (1)のように定め た。空間距離に基づいた分析結果からは事務所と住宅は約 $2 \mathrm{~km}$ の空 間的なラグをもって立地していることが伺えるが，自動車利用者の 観点からみると, 約 4 分と約 6 分の二つの時間的なラグをもってこ れらの施設が立地していることがわかる(図 10 (2) )。

最後に新橋周辺の地域について幅員 $8 \mathrm{~m}$ 以上と $8 \mathrm{~m}$ 未満の道路を区 別して集計を行い分析した。その結果を図 11 に示した。まず，事 務所建築物の空間的自己相関についてみると幅員 $8 \mathrm{~m}$ 未満の道路に 立地する施設を基準として幅員 $8 \mathrm{~m}$ 未満の道路に立地する施設をみ た場合 (以下，「8m 未満三未満」のように表す）の空間的自己相関 の值が $1 \mathrm{~km}$ 付近まで高い值となっており, 事務所がこの地域では幅 員の狭い道路に沿って連担していることがわかる（図11 (1))。次に, 事務所建築物と住宅施設の空間的相互相関をみると，「8m 未満 $\Rightarrow 未$ 満」および $58 \mathrm{~m}$ 未満 $\Rightarrow$ 以上」場合の值が $2 \mathrm{~km}$ 付近で高い (図 11 (2) )。 幅員 $8 \mathrm{~m}$ 未満の道路に立地した事務所建築物と幅員に関係なく立地 する住宅が $2 \mathrm{~km}$ の空間ラグをもって立地する傾向にあることが，幅 員を考慮しない場合（図 10 (2)）よりも一層鮮明に把握することが できる。

\section{6. まとめ}

本研究では, ユークリッド空間で定義されていた従来の空間相関 分析をネットワーク空間へ拡張する方法を考案し，その有効性につ いて検討した。また，分析対象や目的に応じた計算方法のバリエー ションを考案し，実際の都市施設の空間分布に関するデータを用い て分析事例を示した。

\section{謝辞}

匿名の查読者からたいへん貴重なご指摘を数多く頂戴した。ここ に記して謝意を表したい。

注

注 1) 四茂野 ${ }^{12)}$, 北村・岡部 ${ }^{13)}$, 山田・岡部 ${ }^{14)}$, 塩出・岡部 ${ }^{15)}$ などを参照 されたい。また, 東京大学空間情報科学研究センター (CSIS) を中心と してネットワーク空間における空間分析のためのソフトウェアが開発さ れ，実用化されている ${ }^{16)}$ 。

注 2) 本稿で提案する方法は地点間の空間変量の相関関係を「空間ラグ」の 関数として捉える方法である。そのため, メッシュデータのようにあら かじめ区切られたデー夕を利用する場合, セル間の等距性が保存されて いなければならない。塩出・岡部が提案する方法 ${ }^{17)}$ は，ネットワークの 内部にどのセルにも属さない半端なリンクが現れないように, ネット ワーク全体をそれぞれのリンク長が等しいセル集合に区切るためのアル ゴリズムであり，七ル間の等距性は保存されていない(下図参照)。

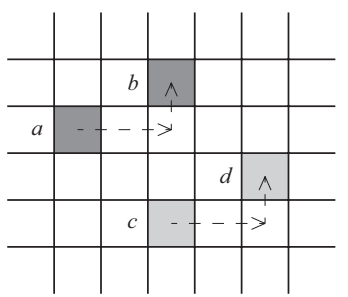

上図は二次元空間をそれぞれの メッシュの大きさが等しくなるよ うに区切ったものである。

$a, b$ 及び $c, d$ の 2 組のペアは, と もに横方向に 2 メッシュ, 縦方向 に 1 メッシュ離れたメッシュのペ アであり,メッシュ間の距離はど ちらのペアも等しい。

一般にメッシュデータにおいて は, 2 つのメッシュが縦方向, 横 方向にそれぞれメッシュ何個分離 れているかが同じであれば,メッ シュ間の距離は等しくなる。

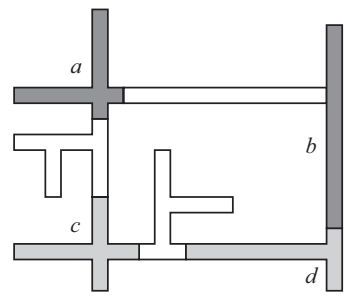

上図はネットワーク空間をそれぞ れのセルのリンク長が等しい長さ になるように区切ったものである。 $a, b$ 及び $c, d$ の 2 組のペアは, と もに2セル離れたセルのペアであ るが, それぞれのセル間の距離は 等しくない。

ネットワーク空間を等しい長さ に区切ったセルデータにおいて は, 2 つのセルがセル何個分離れ ているかが同じでも，セル間の距 離は一般には等しくならない。
注 3) 点分布を密度変換する方法として, Okabe らによるカーネル密度法 ${ }^{18}$ 等がある。この方法を用いれば，ネットワーク空間における空間変量を 離散化せずに, 連続変量のまま分析することが可能である。しかし, 本 稿では, メッシュデー夕を用いる従来の方法との対比を図るために, バッ ファが受け持つ領域の大きさで基準化することにより，密度変換を行い， 空間変量を離散化して分析する。

注 4) ランダムなポイントの発生数 $\mathrm{s}$ が多いほど信頼度の高い推定を行うこ とが可能である。ポイントの発生数 $\mathrm{s}$ の目安については，次報で報告し たい。 


\section{参考文献}

1) Ripley, B. D. : Spatial Statistics, John Wiley and Sons, 1981

2)Clark, P. J. and Evans, F.C. : Distance to Nearest Neighbor as a Measure of Spatial Relationships in Populations, Ecology Vol.35, pp. $445-453,1954.10$

3) Clark, P. J. and Evans, F.C. : On Some Aspects of Spatial Patterns in Biological Populations, Science Vol.121, pp.397-398, 1955. 3

4) Berry, B. J. and Marble,D.F. : Spatial Analysis: A Reader in Statistical Geography, Prentice-Hall, 1968

5) Roach, S. A. : The theory of Random Clumping, Methuen, 1968 6)Cliff, A. D. and Ord, J.K. : Spatial Autocorrelation, Pion, 1973 7) Getis, A : A history of the concept of spatial autocorrelation: a geographer's perspective, Geographical Analysis Vol.40, pp. 297-309, 2008. 7

8）青木義次：メッシュデータ解析の一方法としての空間相関分析法の提案 一その 1 メッシュデータ解析の問題点と空間相関分析法の理論, 日本建 築学会計画系論文報告集，第 364 号, pp. 94-101，1986.6

9）青木義次：メッシュデータ解析の一方法としての空間相関分析法の提案 一その 2 土地利用の連担性・共存性・排斥性の計量化一の応用, 日本建 築学会計画系論文報告集，第 368 号, pp. 119-125, 1986.10

10）青木義次：メッシュデータ解析の一方法としての空間相関分析法の提案 一その 3 空間影響関数モデルの有効性と問題点, 日本建築学会計画系論 文報告集，第 377 号, pp. 29-35, 1987.7

11）腰塚武志，小林純一：道路距離と直線距離, 日本都市計画学会学術研究 発表会論文集，18，pp. 43-48，1983
12）四茂野英彦：ネットワーク上での最近接距離分布の計算可能性, GIS 理論と応用, Vol. 1, pp. 67-56, 1993.3

13）北村賢之, 岡部篤行：道路ネットワーク上における商圈確定法, GIS 一 理論と応用, Vol. 3, No. 1, pp. 17-24, 1995.1

14）山田育穂，岡部篤行：ネットワーク空間における K 関数法，GIS 一理論 と応用, Vol. 8, No. 1, pp. 75-82, 2000.3

15）塩出志乃，岡部篤行：ネットワーク上の点分布から多層的集塊性を抽出 する空間分析手法の提案, 及びその実装に関する研究, GIS 一理論と応用, Vol. 12, No. 2, pp. 79-87, 2004. 12

16）奥貫圭一，塩出志乃，岡部篤行，岡野京子，金子忠明：ネットワーク上 の空間分析のためのソフトウェアSANET 第 3 版の開発，地理情報システ ム学会講演論文集, Vol.14, pp. 113-116, 2005.9

17）塩出志乃, 岡部篤行 : ネットワーク・セルカウント法を用いた点分布の 分析, GIS 一理論と応用, Vol. 12, No. 2, pp. 57-66, 2004. 12

18) Okabe, A., Satoh, T. and Sugihara, K : A kernel density estimation method for networks, its computational method and a GIS-based tool, International Journal of Geographical Information Science, Vol.23, Issue 1, pp. 7-32, 2009

19）内藤智之, 大佛俊泰 : ネットワーク距離に基づく空間相関分析, 日本建 築学会大会学術講演梗概集 $(F-1)$, pp. 939-940, 2008.9

20) 内藤智之, 大佛俊泰 : 道路ネットワーク空間における空間相関分析, 地 理情報システム学会講演論文集，Vol.17, pp.107-110，2008.10

（2009年 5 月 9 日原稿受理，2009年 8 月 21日採用決定） 